THURSDAY, JULY 15, ISSO

THE NEW MLISEUM OF NATURAL. HISTORY

$M^{R}$. WATERHOLSE'S new building at South I Kensington has, we belicve, been formally handed over to the trustees of the British Museum, and as will be scen by their Report, which we give in another column, it is in contemplation, or was so at the time the report was drawn up, to remove several portions of the natural history collections on to the new site during the present year. Up to this time, however, little has been done in the matter. The only beasts and birds to be seen in the new building are those stone inages which it has pleased Mr. Waterhouse to place upon the corbels without and upon the pillars within. It is perbaps only fair that if the inside is devoted to natural history the outside should be similarly devoted to unnatural history, and architects must have their way. It may also be observed that if the trustces bave really taken possession they have sadly neglected their garden department, for the vacant space round the building, which was nicely laid out last year, has been allowed to become overrun with wceds and rubbish. There are two subjects, we believe, which have caused some delay in the proposed removal-the questions of the library and of the mode of government of the new institution. The last-named and most important point being, as the Secretary of the Treasury had stated, still "under the consideration of my Lords," we will make so bold as to tender them a few words of advice on the former subject which also requires their serious attention.

A Library of Reference is, as we need hardly tell the readers of NATERE, an indispensable addition to a Museum of Natural History. No scientific work can bc done without it. Of this we may remark the trustees appear hardly to have been aware, if, as we are informed is the case, there is no special room set apart for a library in the new museum. Had the trustecs put aside a thousand a year, out of their annual grant of $10,000 l$. for printed books, for this purpose, when it was first determined to remove the natural history collections ten years ago, there would have been by this time in existence a library fully adequate for the purpose. But no provision of this sort appears to have been thought of, and it is only within the last year or so, when the building is ready and the time is come to remove the natural history collections into their-new quarters, that any application for the neccssary funds to buy a library has been madc to the Treasury.

Now the special function of the Secrctary of the Treasury is, as everybody knows, to kcep down expencliture. We need not, therefore, be surprised if when the rcqucst was made to him for $30,000 l$. to buy a library of natural history books Sir Ralph Lingen stood rather aghast, and dcmanded time to consider the subject. But even were this great official most benevolently disposed towards the new natural history museum and ready to produce the sum demanded at once it would not by any means enable the trustees to mect the object in view. It is by no means simply a case of going into the market and ordering all the books required of the first bookseller. The greater number of the works required are out of print, and only to be Vor. XxII.-No. 559 picked up at scattercd intervals at second-hand shops. To cndeavour to purchase them all at a moment's notice would be simply useless. This is another reason why the policy above recommended of collecting the required library by slow degrees should have been adopted.

There is now in fact only one way out of the difficulty. It is a very simple one, but we fear the trustces will not like it. The naturalists and students of the British Muscum have hitherto had the use of the Great National Library, which contains all the necessary scientific books. Let these necessary books be removed along with the collections to South kensington, not as a gift, but as a loan to the new institution. Let the trustecs devote an annual sum of such an amount as they can convenicntly employ to their redemption-that is, to the purchase of second copies of these scientific books. $\Lambda \mathrm{s}$ soon as the duplicates are received at South Kensington let the originals be returned to the British Museum. Thus the Great National Library will ultimately recover its own completeness, while at the same time the new museum of natural bistory at South Kensington will be able to start work with a perfect library- which could in no other way be provided for it. Morcover instead of having to find some 25,000 . or $30,000 \%$. at the present moment, the Treasury will be able to spread the necessary expenditure over several years, during which it is certain that many of the rarer volumes unattainable at the present moment will come into the market. The only objection to this plan that we can see is that it will be sometimes necessary to refer an applicant for a particular volume at the reading-room of the British Muscum to South Kensington. I3ut when it is once understood that the natural history books are at South Kensington people will very soon learn to go there for them.

The real difficulty in the present situation is that the control of the whole museum is in the bands of the principal librarian, who naturally enough prefers the interests of the library to that of the natural history. He is glad enough to get rid of the beasts and birds, but when you ask him to give up, even temporarily, a portion of the books it is quite another question. Very few of the trustees who are nominally his masters carc anything for natural history, so that from that quarter no intervention can be lookcd for in favour of the scheme we have put forward. The only way in which it can be carried out is by the vis major of the Treasury, which, as the plan is not only advantageous, but also economical, should surely be exerted in its favour.

If the Government had taken the advice of the Duke of Devonshire's Commission, and handed over the natural history collections to a director under the control of the Department of Science and Art, there would have been some one sufficiently interested to make a stir on the subject. As the matter now stands the principal librariar: can of course do as much as he pleases, and will, no doubt, keep his books in Bloomsbury as long as possible.

\section{ELEMENTARY EDUCATION}

I ORD NORTON and his friends seem determined to L take every opportunity of hunting down the present system of education in Government elementary schools 